\title{
ANALYZING SUSTAINABILITY ISSUES IN URBAN LOGISTICS IN THE CONTEXT OF GROWTH OF E-COMMERCE
}

\author{
Patrick Siegfried ${ }^{1} *$, ORCID ID: 0000-0001-6783-4518, \\ Alex Michel $^{1}$, ORCID ID: 0000-0003-1257-141X, \\ Jan Tänzler ${ }^{1}$, John Jiyuan Zhang ${ }^{2}$ \\ ${ }^{1}$ International School of Management, Mörfelder Landstraße 55, Frankfurt, Germany \\ ${ }^{2}$ International School of Management, Brooktorkai 22, Hamburg, Germany \\ *Corresponding author: Patrick Siegfried, patrick.siegfried@ism.de
}

Received: 01. 22. 2021

Accepted: 02. 26. 2021

\begin{abstract}
E-commerce has been keeping fast increasing worldwide since beginning of the $21^{\text {st }}$ century. Rapid growth of e-commerce \& parcel shipping is a booming business. However, how to handle with many hard-to-solve sustainability issues of transport in urban areas, is becoming a serious challenge for urban logistic sector and numerous stakeholders. The sustainability issues contain the problems of air pollution, congestion, and sub-contractors. This paper reported those issues in the context of growth of e-commerce and analyzed their efforts on the sustainable urban logistics development.
\end{abstract}

Keywords: E-commerce, Last-mile delivery, Logistic solution, Parcel shipping, Transport, Sustainability, Urban logistic.

Rezumat. Comerțul electronic a crescut rapid în întreaga lume de la începutul secolului 21. Creșterea rapidă a comerțului electronic și a transportului de colete este o afacere în plină expansiune. $\mathrm{Cu}$ toate acestea, modul de a face față multor probleme de durabilitate, greu de rezolvat ale transportului în zonele urbane, devine o provocare serioasă pentru sectorul logistic urban și pentru numeroasele părți interesate. Problemele de durabilitate includ aspecte legate de poluarea aerului, congestionare și subcontractanți. Prezentul articol examinează aceste probleme în contextul creșterii ponderii comerțului electronic și a eforturilor atestate în vederea dezvoltării logistice urbane durabile.

Cuvinte cheie: comerț electronic, livrare pe ultima sută de metri, soluție logistică, transport colete, durabilitate, logistică urbană.

\section{Introduction}

The sales of e-commerce have keeps rapidly growing globally [1]. In 2019, retail ecommerce sales worldwide amounted to 3.53 trillion US dollars and e-retail revenues are projected to grow to 6.54 trillion US dollars in 2022 [2]. Online shopping is one of the most popular online activities worldwide[3]. At the same time, according to Pitney Bowes' Parcel Shipping Index (2020) [4], there were 103 billion parcels shipped worldwide in 2019, it reveals growth of $18 \%$ from 2018, Worldwide are 3,248 parcels shipped every second. This report forecasts that by 2026 , the total volume of parcel shipping would be more than double as recently and achieve to 220 to 262 billion. 
In urban contexts, logisticians, authorities, and citizens face a multiplicity of challenges. First, there are freight externalities that authorities and citizens would like to prevent. It is common to see in urban logistics literature citizen's vested interests in public measures to tackle freight externalities with the aim of promote sustainability and livability [5].

Moreover, there are also problems with space, access, and distance in urban areas that logisticians and authorities face on a regular basis. This depends strongly on availability and development of transport systems, infrastructure, efficient fleet, better transportation modes, companies' sustainability policies, and so on [6].

Also, the delivery speed it another challenge, especially if the logistic companies have the aim is to deliver in a profitable and sustainable way.

\section{Distribution channels for E-commerce}

The growth of e-commerce has incited the setting of various distribution channels for home deliveries (see figure 1) [7].

Store purchase. Represents the conventional shopping trip to a retail outlet which is supplied by truck deliveries from regional distribution centers (DC).

Store delivery. Involves home deliveries originating from a store location for goods that could have been purchased in store or ordered online. This is particularly the case for bulky (appliances) or perishable (food) purchases.

Home delivery. An online order processed by a fulfillment center (FC) and delivered to the home address of the purchaser (at times to an alternative location such as the workplace). This represents the conventional online purchase delivery chain.

Pick up. A series of options for deliveries that are an alternative to home deliveries. Locker boxes or collection points offer lower cost alternatives than direct home deliveries and the option to pick up a parcel at a time that matches better the consignee's availability. 'Click-and-collect' schemes are emerging pickup strategies implemented by several grocers where online orders are picked up at a designated area such as the parking lot adjacent to the grocery store.

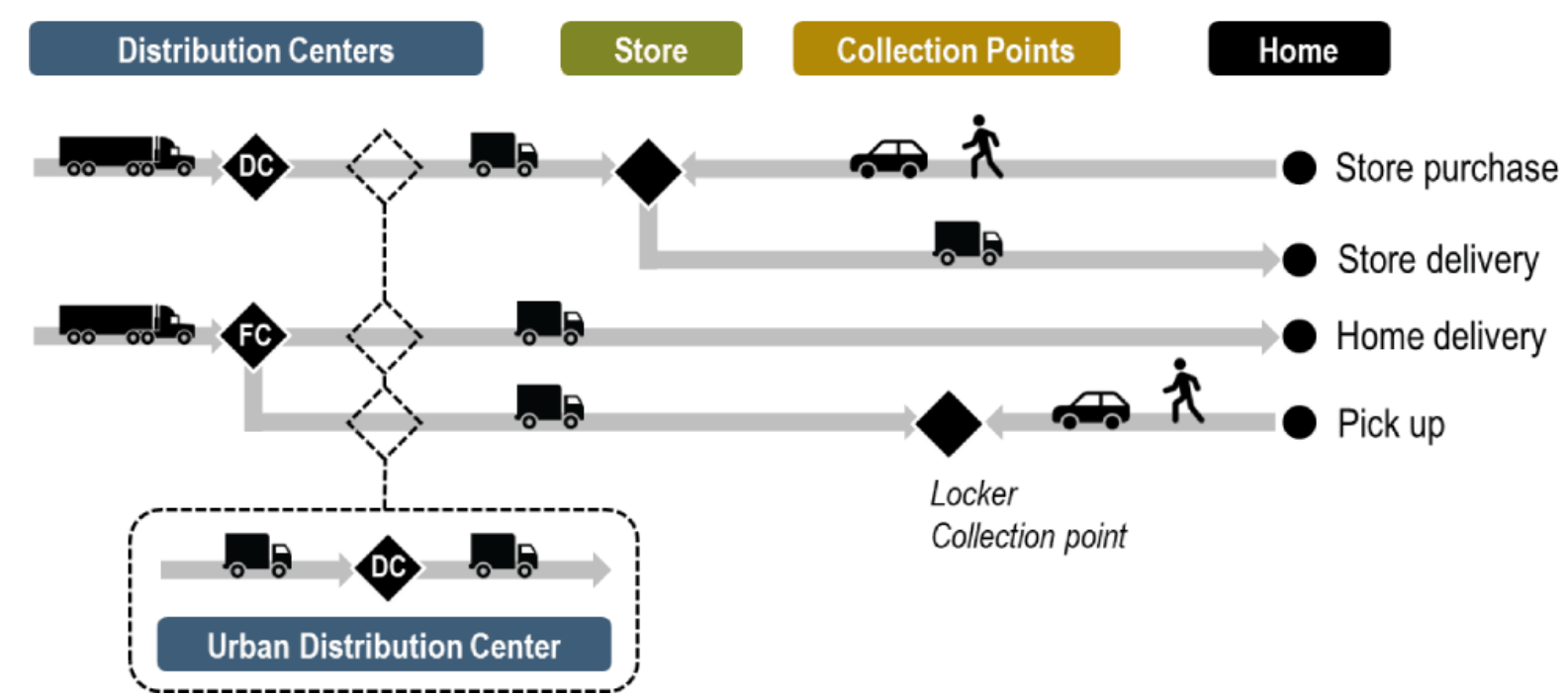

Figure 1. Distribution Channels for E-commerce. Source: Metrofreight consortium, 2020.

In the context where there is increasing congestion and volumes of deliveries, the setting of urban distribution centers becomes a value proposition.

For instance, sortation centers are emerging as intermediary locations to assign deliveries to specific areas. 


\section{Challenges to urban freight companies}

Meet to characters of E-commerce, the logistical systems of many companies are not sufficient to manage the new challenges. There are three main challenges in relation to ecommerce:

1) Challenge to fast and small-size deliveries. E-commerce customers are increasingly demanding faster transportation and with increased service quality. Many e-commerce users have a belief that online products must be shipped as soon as possible after the order is made. Responding to the increased demand of fast and small-sized frequent shipments incurred by ecommerce has become one of the biggest challenges for logistics express delivery companies. A successful delivery of shipments to consumers distributed across large geographical areas will require re-designing of the existing distribution network including terminals, hubs, and the network paths that connect them [8].

2) Challenge to home delivery. Customers' tendency to purchase separate items from several different web-based companies (each requiring separate delivery), additional sortation requirements to combine multiple customers' orders prior to delivery [9]. Highly bundled shipments to retailers are substituted with far less bundled shipments to end consumers. Therefore, retailer and manufacturer will have to reconfigure their established logistics systems from consolidated shipments to small packages. This development is often criticized for causing increased traffic.

3) Challenge to reverse logistics. The increasing challenge in reverse logistics today is the growth of returns resulting from the rise of e-commerce. Reverse logistics is concerned with managing the movement of goods back to manufacturers, distributors, and retailers, because they are the wrong size, broken, out of date, or are not actually ordered. While returns rates to stores are around $8 \%$, this jumps to around $25 \%$ for items bought online. $30 \%$ of shoppers deliberately over-purchase and subsequently return unwanted items. 19\% admitted to ordering multiple versions of the same item so they could make their mind up when they are delivered [10].

\section{Sustainability issues in urban logistics}

\subsection{Air pollution}

As for air quality in cities, organization of transport is a remarkable problem. Transport processes are the origin of air pollution and waste such as tyres, oil and other materials. Air pollution is an especially burdensome factor, because it means harm to people's health as well as deterioration of living conditions. Quality of air is one of the Local Agendas 21 indexes which determined the sustainability of a city at a local level. Waste and landfilling are another important problem in a city. Landfills generate particulate and gaseous pollution which considerably influences the quality of air. Organizing waste management is no longer merely an obligation, but a challenge for city authorities. The difficulties include the growing area of landfills and inhabitants' reluctance toward starting new ones [11].

Last-mile Logistics is considered as the most expensive and polluting segment in the entire supply chain network [12]. With increasing concerns over the impact of this segment on environment, necessary steps were taken to reduce the Greenhouse Gas (GHG) emissions. But, with rapid increase in customer demand for Last mile logistics, innovative strategies need to be developed to limit the GHG emissions [13]. A recent study of EU countries shows that in $60 \%$ of cities, there are significant difficulties in terms of urban logistics management; $55 \%$ of vehicle emissions are caused by goods distribution [14].

In major cities, commonplace obstacles like road closures, construction, heavy traffic, and even parking restrictions make the last mile remarkably time- and energy-consuming. For example, London recently announced the expansion of its ultra-low emission zone, making the 
deployment of last-mile delivery vehicles even more complicated for logistics companies. On the other hand, in more remote areas, the infrastructure (or lack thereof) as well as a low volume of deliveries often render the logistics excessively inefficient. Carbon dioxide emissions from freight transportation account for $30 \%$ of all transportation-related carbon emission from fuel combustion [15].

\subsection{Congestion}

The disproportionate expense of the last mile delivery is caused by the difficulty of reaching end-customers, particularly in congested urban areas. The boom in e-commerce makes it even more difficult to distribute the package at a convenient time for both carrier and customer. All packages tend to be delivered at the end of the day, when customers have finally returned home, but also during rush hours period. The growing number of vehicles in urban areas implies increased congestion, while delayed deliveries have a detrimental impact on customer satisfaction [16].

Demand for urban last mile delivery is expected to grow by four-fifths (78\%) by 2030 , leading to $36 \%$ more delivery vehicles in inner cities. In turn, traffic congestion is forecast to rise by over $21 \%$, the equivalent of adding 11 minutes to each passenger's daily commute, according to The Future of the Last-mile Ecosystem analysis [17].

In 2015, Americans were stuck in traffic for eight billion hours, with Los Angeles commuters each spending more than 104 hours a year in congestion. This is not a uniquely American problem: commuters in Moscow spend more than 90 hours stalled in traffic and similar delays are found in Bogota (79 hours), Sao Paolo (77 hours) and London (73 hours) [18]. According to the survey for UPS and GreenBiz, when asked to identify the top issues of concern in regard to the urban environment, 53 percent noted traffic congestion. This far surpassed other factors such as more convenient public transit, safety and traffic noise. Many cities are trying to move some of those trips to other modes such as mass transit, biking or walking, and away from personal vehicle use because for most cities, there is no more available land to build more roads.

Traditionally, smaller, on-demand delivery companies design logistics processes and distribution networks that are based on dynamic responsiveness, rather than efficiency. This will not be sustainable moving forward. A high proportion of freight and service transport in cities takes place during peak hours on the road network. At the same time, trends in supply chains and logistics management together with changes in the behavior by business and private consumers are leading to increased fragmentation of last mile deliveries. The combined result of this is that more vehicles are trying to make more deliveries at the same time and the infrastructure available (road space and curbside space) cannot cope.

Road congestion will increasingly impact upon the functioning of world urban locations freight network. Freight movement across city centers will become more challenging as delivery vehicles negotiate higher levels of traffic congestion, particularly in the "last mile" of parcel delivery. The challenges of increased pollution and congestion are being compounded by the rise in $\mathrm{B} 2 \mathrm{C}$ or E-commerce. Urban customers tend to order more online and those goods are shipped to him or her directly rather than being picked up at a retail store.

Many cities suffer from problems of traffic congestion and have introduced some form of congestion charging that has implications for freight transport. Similarities in trends are clear with a growing number of smaller vehicles being used in urban supply chains. Using of smaller vehicles is a complicated mix of regulatory issues and trends towards a more fragmented last mile delivery system in urban areas. This has consequences for congestion patterns because the nature of the loading and unloading patterns for the vans is very different from that applying to trucks where more specialized space is often required. 


\subsection{Workloads and subcontractors}

Workloads for parcel deliverers have risen substantially in recent years. These days a single courier easily handles as many parcels as two couriers would have delivered 15 to 20 years ago according to report of [19]. Employees and self-employed parcel deliverers in many cases do not receive a fixed income but instead are paid per delivery. Thus, they are forced to work extremely long hours to cover their costs. Couriers are contracted by subcontractors and sometimes even by sub-subcontractors [19]. However, while the number of packages has risen steadily, the cost of sending them has not. Giant retailers like Amazon put pressure on delivery companies and the price per package delivered keeps falling [20].

Another example to problem of parcel delivery drivers' workloads is the giant online retailer Amazon. With Amazon's rapid growth, the environment for drivers is getting only more demanding. Amazon delivered over 5 billion Prime packages worldwide in 2017 [21]. To ensure that millions of packages are delivered each day, Amazon employs some drivers through its Amazon Flex program. The Flex drivers work directly with Amazon. They make their own hours and are their own bosses. Many drivers described a variety of alleged abuses, including lack of overtime pay, missing wages, intimidation, and favoritism.

Subcontractors are witnessing enormous cost pressure which they pass on to their couriers. DPD and GLS, PS and DHL in Hungary, the Czech Republic and Austria are handling all their parcel deliveries through subcontractors. According to [20], DPD alone works with about 1.000 sub-contractors from whom 11.000 couriers' work in 2018 and for Christmas, another 4.000 drivers would be added. Hermes and Trans-o-flex in Germany have also "outsourced" most of their couriers. Seeing as sub-enterprises in Germany are not usually bound by collective agreements, their wages do not conform with those set out in the said agreements in force. In Austria collective agreements for small transport enterprises apply yet the regulations under such agreements are frequently ignored. This keeps couriers' wages low and even full-time employment in many cases does not secure their livelihood [19].

\section{Conclusion}

Meet to fast growth of e-commerce, urban logistic sector faces to handle many new challenges due to sustainable development. For urban logistic companies, the main challenges are the fast delivery, home delivery with small-size delivery, and storage management in terms of high return rate. Besides that, air pollution throughout transportation process in urban areas, congestion in terms of numerous delivery vehicles in inner cities and critical sub-contractors of logistic companies are other sustainability issues. Obviously, to solve those complex sustainability issues, a functional co-operation concept with wide range of stakeholders, such as public administration, entrepreneurs, academics, Non-governmental organizations (NGOs), and citizens, is necessary.

\section{References}

1. Siegfried P. (2014). Onlinehandel erfolgreiche Unternehmenskonzepte. Band 1. AVM Akademische Verlagsgemeinschaft.

2. Statista, Retail e-commerce sales worldwide from 2014 to 2023 [online]. 2020. [accesat 30.11.2020]. Disponibil: https://www.statista.com/statistics/379046/worldwide-retail-e-commerce-sales/\#statisticContainer

3. Siegfried P. (2020). Handel 4.0 - Erfolgreiche Unternehmenskonzepte mit Arbeitsfragen und Lösungen Showroom. BoD Book on Demand.

4. Pitney Bowes. 2020. Parcel Shipping Index. Darmstadt. Germany

5. Munuzuri J., Cortés P., Guadix J., and Onieva L. City logistics in Spain: Why it might never work. In Cities, 2012. 29 (2), pp. 133-141.

6. Anderson S., Allen J., and Browne M. Urban logistics-how can it meet policy makers' sustainability objectives? In: Journal of Transport Geography, 2005, 13(1), pp. 71-81.

7. MetroFreight Consortium. City logistics: concepts, policy and practice. [online] 2020. [accesat 23.03.2020] Disponibil: https://globalcitylogistics.org/?page_id=426 
8. Aranko J. Developing the last mile of a parcel delivery service concept for consumers [online] Laurea Leppävaara: Laurea University of Applied Sciences, 2013. [accesat 28.01.2021]. Disponibil: https://core.ac.uk/download/pdf/38098124.pdf

9. Edwards J., Mckinnon A., and Cullinane S. Carbon Auditing the 'Last Mile': Modelling the Environmental Impacts Modelling the Environmental Impacts Non-food Shopping. In: Annual Conference of the Logistics Research Network 2009. Cardiff 09-11 September 2009, Edinburgh: Heriot-Watt University, 2009, p. 7.

10. Charlton G. Ecommerce Returns: 2020 Stats and Trends [online]. 2020. [accesat] 15.01.2020). Disponibil: https://www.salecycle.com/blog/featured/ecommerce-returns-2018-stats-trends/

11. Mesjasz-Lech A. Urban air pollution challenge for green logistics. In: The 2nd International Conference "Green Cities - Green Logistics for Greener Cities, Szczecin, 2-3 March 2016. Amsterdam: Transportation Research Procedia, pp. 355-365.

12. Siegfried P. Zhang J. (2021). Developing a sustainable concept for the urban last-mile delivery, Open Journal of Business and Management (OJBM).

13. Awwad M., Shekhar A., and Iyer A. (2018). Sustainable Last-Mile Logistics Operation in the Era of E-Commerce. In: The International Conference on Industrial Engineering and Operations Management Washington DC, 27-29 September 2018, Washington DC: IEOM Society International, 2018, pp. 584-591.

14. Faccio M and Gamberi M. New City Logistics Paradigm: From the "Last Mile" to the "Last 50 Miles" Sustainable Distribution. In: Sustainability. 2015, 7(11), 14873-14894.

15. Transmetrics. How Artificial Intelligence Can Improve Sustainability in Last-Mile Delivery [online]. 2020. [accesat 17.02.2020]. Disponibil: https://transmetrics.eu/blog/how-artificial-intelligence-can-improve-sustainability-inlast-mile-delivery/

16. Chammas K. Logistics in cities, the challenge of last-mile delivery [online]. 2020. [accesat 24.03.2020] Disponibil: https://www.ab-europeanrealestate.com/news/market-commentary/last-mile-logistics/

17. Weekes S. E-commerce delivery emissions on track to increase $30 \%$ in cities by 2030 [online]. 2020. [accesat 14.01.2020]. Disponibil: https://www.smartcitiesworld.net/news/news/e-commerce-deliveries-could-see-30rise-in-city-carbon-emissions-4931

18. UPS \& GreenBiz. The Road to Sustainable Urban Logistics. [online]. Atlanta, GA: United Parcel Service of $\begin{array}{llll}\text { America } & \text { and 2017.01.2021]. }\end{array}$ https://sustainability.ups.com/media/UPS_The_Road_to_Sustainable_Urban_Logistics.pdf

19. FORBA. Precarious working conditions in the parcel services: To take a stand. Wien: Verlag des ÖGB GmbH, 2018.

20. Shaer C. The dark side of Germany's online shopping boom [online]. 2020. [accesat 18.11.2018] Disponibil: https://www.handelsblatt.com/english/companies/courier-rights-the-dark-side-of-germanys-online-shoppingboom/23694948.html

21. Peterson H. Missing wages, grueling shifts, and bottles of urine: The disturbing accounts of Amazon delivery drivers may reveal the true human cost of 'free' shipping [online]. 2020. [accesat 11.08.2018] Disponibil: https://www.businessinsider.com/amazon-delivery-drivers-reveal-claims-of-disturbing-work-conditions-2018$8 ? \mathrm{r}=\mathrm{DE} \& \mathrm{IR}=\mathrm{T}$ 